International Journal of Heritage, Tourism and Hospitality Vol. (13), No. (2), September, 2019

By: Faculty of Tourism and Hotels, Fayoum University

\title{
Evaluating the Staff Performance at the Food and Beverage Department: A Comparative Study Between the Hotels of Egyptian Company of Tourism and Hotels (EGOTH) and Accor Hotel Chain
}

Ahmed Hassan Mohamed Mohamed Abdelwahab Morsy Mohamed Sheded Hassan

Faculty of Tourism and Hotels- Fayoum University

\begin{abstract}
As appraisals are considered one of the most problematic and challenging modules of human resource management in hotels, This study discusses the evaluation of staff performance at the food and beverage department, and compare between the hotel of Egyptian company of tourism and hotels (EGOTH) and Accor hotel chain. Primary data was collected using a questionnaire survey of managers and supervisors in the hotel of Egyptian company of tourism and hotels (EGOTH) and Accor hotel chain. Finally, the correlation test was conducted to identify the relationship between the challenges of the performance appraisal process and the employees' performance appraisal in the hotels under study. The results indicated that there is a significant and negative relationship between challenges of the performance appraisal process and employees' performance appraisal in the food and beverages department in both E.G.O.T.H. and Accor hotels. Finally, this study recommended that these hotels should Set clear criteria for employees' performance appraisal, characterized by fairness, accuracy, and objectivity, and emphasizing that the performance appraisal process aims to develop and improve their performance and address the shortcomings of performance rather than punishment.
\end{abstract}

Keywords: Performance, Performance Appraisal, E.G.O.T.H., Accor.

\section{Introduction}

Employees performance considers the main source of achieving organizational effective and organizational success (Koopmans et al.,2013). Organizations' success in achieving its objectives and succeeding in making its mission come true depends on the performance of the employees working in it. Additionally, High level of employees' performance will lead to better reaction to competitors, following of rules and regulations, working based on the environmental factors and focusing on reaching the goals (Bakri, 2015). Performance appraisal has become part of strategic approach to integrating Human Resource activities and business policies and seen as a variety of activities through which organizations seek to assess employees and develop their competence, enhance performance and distribute rewards (Fletcher and Perry, 2001; Abu-Musa, 2008). Performance measurements turns from measuring outputs to measure outcomes (De Vries, 2010). The aims of performance evaluation are strengthen and improve individual performance practices (Awase, 2006), Providing an orderly way of determining promotions, transfers and salary increases, Supplying data to management on the performance of subordinates and to the individual on his or her performance, Creating a learning experience that motivates staff to develop themselves and improve their performance (Kumar, 2005), Identifying systemic factors that are barriers to, or facilitators of, effective performance, improving communication, determining whether HR programmes such as selection, training and transfer have been effective or not, identifying the strengths and weakness of an employee on his present job, and providing feedback to employees about their performance (Khan, 2013). Omusebe et al. (2013) stated that effective performance evaluation leads to many importance outcomes for organizations, such as improving employees' productivity, quality, satisfaction, organizational commitment, organizational justice, and building a truth. 


\section{Research Problem}

Performance appraisal is a vital part of performance management and irrigate to the formal process of assessing and measuring employee performance against agreed objective (Tabeel, 2014). Abu-Musa (2008) indicated some problems facing performance appraisal, are unclear standards, leniency or strictness, halo effect, horns effect, central tendency, relationship effect, lack of objectivity, bias, recent behavior bias, and personal bias. Alquraan (2011) pointed out that in an appraisal discussion, five fundamental areas need to be covered that are; 1)the measurement of results of the employee's performance against goals and standards, 2) recognition of the employee's contributions, 3) correction of any new or ongoing performance problems, 4) training and personal development needs for both current and future applications, and 5) the establishment of goals and/ or standards for the next appraisal period.

As appraisals are one of the most problematic and challenging modules of human resource management in hotels, This study discusses the evaluation of staff performance at the food and beverage department, and compare between the hotel of Egyptian company of tourism and hotels (EGOTH) and Accor hotel chain.

\section{Research Objectives}

A. To evaluate the performance of the employees of the hotel under study.

B. To determine the criteria for measuring the performance of the hotel, and highlight the importance of evaluating performance.

C. To identify the differences in the performance of employees between the public sector represented in the hotels of the Egyptian Company for Tourism and Hotels (EGOTH) and the private sector represented in Accor hotels chain.

D. To identify the most important challenges to improve performance in the investigated hotels.

\section{Research Hypotheses}

A. There is a statistically significant relationship between the challenges of improving performance and evaluating the performance of hotels under study.

B. There are significant differences between the performance of employees in the food and beverages department in the hotels of the Egyptian Company for Tourism and Hotels (EGOTH) and Accor hotels chain.

C. There are differences of statistical significance between the importance of evaluating the performance of employees in the Food and Beverage department of the hotels of the Egyptian Company for Tourism and Hotels (EGOTH) and Accor Hotel Chain.

\section{Literature review \\ Performance Appraisal Definition}

The first recorded performance appraisal dates back to the third century when a Chinese philosopher criticized one of his colleagues for being biased and did not judge men by virtue of their work, but according to his own preferences (Plessis, 2015). Performance appraisal is part of the performance management process, as the quality and accuracy of performance appraisal will effectively impact performance management activities. Avey et al. (2009) indicated that the performance appraisal is a review and discussion of the employees' performance of the tasks and responsibilities assigned to them. Proper performance appraisal also helps identify the skills and abilities that are already required to achieve the required tasks within an organization. Performance appraisal is an assessment and classification of staff through the manager annually 
(Armstrong, 2006). Performance appraisal aims to improve performance and the value of appraisal itself (Yao and Li, 2014).

Milka et al. (2015) explained that performance appraisal is a formal administrative system that provides an effective assessment of the quality of the employees' performance within the organization. The appraisal can be done through supervisors directly. This requires supervisors to fill out a form designed to evaluate the employees according to several axes, and discuss the results of the appraisal with the staff. Khan (2016) mentioned that performance appraisal is the process of identifying, evaluating, and improving the performance of the employees of the organization according to their competence in achieving organizational objectives. At the same time, staff benefit from the appraisal by promotions, feedback, guidance, and development.

\section{The Importance of Performance Appraisal}

According to Gürbüz and Dikmenli (2007), there are several motivations for organizations to evaluate performance, such as improving staff performance by providing feedback to employees on strengths and weaknesses and contributing to the identification of compensation, training needs, and promotions, and the development of employees skills through further training and education. Thus evaluating and rewarding them, which in turn leads to better productivity for the company (Plessis et al. 2016).

Dessler (2009) reported that there are major reasons for evaluating employees performance. The first is to help managers make decisions about salaries and incentives and to promote the best employees. The second is to provide an opportunity to discuss and support the performance appraisal results among managers, supervisors, and employees. The third is the ability to use performance appraisal results as a tool to support employees by identifying strengths and weaknesses, identifying their training needs, and addressing weaknesses in their performance.

There are many benefits to performance appraisal of both the organization and employees. For the organization, performance appraisal contributes to:

- Identify the achievement of the organizations' objectives.

- Detect some defects and problems of organization.

- Provide the necessary foundations for the development of future plans related to the employees' performance such as training, development and human resources planning (Milka et al. 2015).

- Supervise of heads of departments (Karatepe, 2013).

- Increase commitment of staff (Jonsson and Jeppesen, 2012).

- Retain excellent employees (Kim, 2014).

- Achieve training objectives by accurately identifying training needs (Anso, 2014).

- Build a strong relationship between employees and management and getting closer to the employees to identify their problems (Sudin, 2011).

- Increase the employees' loyalty to the organization (Gilley et al., 2009).

Kaliprasad (2006) revealed that the main objectives of performance appraisal are allowing employees to discuss their performance with the supervisor or manager, identifying the strengths and weaknesses of the employee's performance, and providing a basis for future work tasks and salary recommendations. Additionally, Elnaga and Imran (2013) depicted that the objectives of the performance appraisal are reviewing staff performance over a specified period of time, judging the gap between actual performance and desired performance, assisting management in exercising regulatory control, strengthening the relationship between senior subordinates and 
management - staff, diagnosing of the strengths and weaknesses of individuals to determine the needs of training and development for the future.

\section{Methodology \\ Questionnaire design}

The current study adopted a quantitative approach using the questionnaire as a tool for data collection to test the study hypotheses and achieve its objectives. The methodology designed for the current study, was guided by the primary study hypotheses and the subsequent study objectives.

The study focused on evaluate employees' performance in hotels of Egyptian Company of Tourism and Hotels (E.G.O.T.H.) and Accor Hotel Chain, as well as to identify the differences between the Employees' performance between the public sector represented in hotels of Egyptian Company of Tourism and Hotels (E.G.O.T.H.) and the private sector represented in the Accor Hotel chain. The study also aimed to identify the challenges facing the performance appraise process in the hotels under study, and the relationship between these challenges and the evaluation of employees' performance of these hotels. Hence, the researcher found that the quantitative method is an appropriate method to give practical significance to this study. In this regard, the current study adopted the quantitative tool, which included a mixture between adapted and developed questions.

The questionnaire in this study is broken into four parts. Part on includes respondents' demographic profile. Part two consisted of 15 items adapted through extensive literature scanning, listed questions about evaluating the importance of performance appraisal process for hotels and employees. Part three included 22 item adapted from extensive review of the literature, listed questions about appraising employees' performance. Part four included 19 item adapted from extensive review of the literature, listed questions about indicating challenges facing performance appraisal process.

\section{Population and sampling}

The study targeted all managers and supervisor in hotels of Egyptian Company of Tourism and Hotels (E.G.O.T.H.) and Accor Hotel Chain especially food and beverages department. The questionnaires were distributed during the period from November 2018 to February 2019. 320 questionnaires were collected of 340 distributed by $94.1 \%$ of response rate. 288 of them were valid and had no missing data, while the other 32 were invalid because of missing data and they were excluded from all computation.

\section{Data collection tool \\ Primary data sources}

The study was conducted as a questionnaire which is the most popular (quantitative) study design in the social science. Survey study designs are quite flexible and can therefore appear in a variety of forms, but all are characterized by the collection of data using standard questionnaire forms administered by telephone or face to face, by postal or increasingly by using web-based and email forms. The researchers use both hard and online copy questionnaire form. 149 form were collected from the hard copy distribution, while 171 soft copy on Google drive were shared with the managers couldn't met them to get their responses. 


\section{Secondary data sources}

The most common forms of secondary data sources are books, academic journal articles, official governmental statistics, internet data, and other publications. All secondary data sources are indicated in chapter 2 entitled "Literature Review ".

\section{Data Analysis}

The Statistical Package for Social Sciences (SPSS) for Windows v.25 was used to analyze the data collected. The statistics techniques used in this study are:

- Cronbach alpha to assess the reliability.

- Descriptive analyses were performed to investigate the frequency distribution of responses to the relevant questions, Std. deviation and mean.

- Correlation analysis is used to examine the relationships between two or more ordinal or scale variables and depict the strength and direction of the linear relationship between two variables.

- Mann-Whitney test was used to identify the differences between two independent samples.

\section{Results and discussion \\ Reliability}

Reliability coefficient of 0.70 or higher is considered "acceptable" in most social science research situations (Zaki and Al-Romeedy, 2018). As indicated in table (1), the Cronbach Alpha reliability was computed for three sections (B to D) and the tests showed that the reliability coefficients for all the sections were above 0.86 which indicates that the instrument is reliable for being used.

Table (1) Cronbach alpha for study instruments

\begin{tabular}{|l|c|c|}
\hline \multirow{2}{*}{\multicolumn{1}{|c|}{ Sections }} & Cronbach alpha & Cronbach alpha \\
\cline { 2 - 3 } & E.G.O.T.H. & Accor \\
\hline Importance of performance appraisal process & .930 & .877 \\
\hline Appraising the performance of employees & .867 & .911 \\
\hline Challenges of performance appraisal process & .894 & .889 \\
\hline
\end{tabular}

\section{Respondent Demographic Profile}

Table (2) Respondent Demographic Profile

\begin{tabular}{|l|l|c|c|}
\hline \multirow{4}{*}{ Gender } & Demographic variables & Freq. & $\%$ \\
\cline { 2 - 4 } & Female & 258 & 89.6 \\
\hline \multirow{5}{*}{ Age } & & 30 & 10.4 \\
\hline \multirow{5}{*}{ Educational level } & Less than 25 years & 288 & 100 \\
\cline { 2 - 4 } & $25-35$ years & - & - \\
\cline { 2 - 4 } & $>35-45$ years & 78 & 6.3 \\
\cline { 2 - 4 } & $>45-55$ years & 142 & 25.7 \\
\cline { 2 - 4 } & More than 55 years & 54 & 49.2 \\
\hline & & 288 & 18.8 \\
\cline { 2 - 4 } & Mid- scale education & 21 & 100 \\
\cline { 2 - 4 } & Bachelor degree & 236 & 7.3 \\
\cline { 2 - 4 } & Diploma & 14 & -1.9 \\
\cline { 2 - 4 } & Master & - & - \\
\cline { 2 - 4 } & PhD & - & 17 \\
\cline { 2 - 4 } & others & 288 & 100 \\
\hline
\end{tabular}


International Journal of Heritage, Tourism and Hospitality Vol. (13), No. (2), September, 2019 By: Faculty of Tourism and Hotels, Fayoum University

\begin{tabular}{|c|c|c|c|}
\hline \multicolumn{2}{|c|}{ Demographic variables } & Freq. & $\%$ \\
\hline \multirow[t]{6}{*}{ Department } & Kitchen & 54 & 18.8 \\
\hline & Restaurants & 74 & 25.7 \\
\hline & Bars & 66 & 22.9 \\
\hline & cafeteria & 54 & 18.8 \\
\hline & Banquet & 40 & 13.8 \\
\hline & & 288 & 100 \\
\hline \multirow{5}{*}{ Years of experience } & Less than 3 years & 18 & 6.3 \\
\hline & 3-7 years & 65 & 22.6 \\
\hline & $>7-11$ years & 114 & 39.5 \\
\hline & More than 11 years & 91 & 31.6 \\
\hline & & 288 & 100 \\
\hline \multirow[t]{2}{*}{ Job title } & $\begin{array}{l}\text { Manager of Food and } \\
\text { Beverages }\end{array}$ & 112 & 38.9 \\
\hline & $\begin{array}{l}\begin{array}{l}\text { supervisor of Food and } \\
\text { Beverages }\end{array} \\
\end{array}$ & 176 & 61.1 \\
\hline \multicolumn{2}{|c|}{ Total } & 288 & 100 \\
\hline
\end{tabular}

Table (2) indicated that $89.6 \%$ of the respondents are male and $10.4 \%$ are female. Regarding the age of respondents, $49.2 \%$ of the respondents are between $>45-55$ years, followed by who are between $>35-45$ years by $25.7 \%$, then who are more than 55 years by $18.8 \%$, then who are between $25-35$ years by $6.3 \%$. It also indicated there is no one less than 25 years. The majority of the respondents had a bachelor degree $(81.9 \%)$. Moreover, $7.3 \%$ of respondents had a mid-scale education. $5.9 \%$ of the respondents had other educational level and finally, there are $4.9 \%$ of the respondents who had a diploma. Additionally, 25.7\% of the respondents work in restaurants department, followed by who work in bars department by $22.9 \%$, then who work in kitchen department by $18.8 \%$, then who work in the cafeteria by $18.8 \%$, and finally, who work in banquet department by $13.8 \%$. The same table also showed that $39.5 \%$ of the respondents had experience in work for $>7-11$ years, followed by who had experience more than 11 years by $31.6 \%$, then who had experience for 3-7 years by $22.6 \%$ and finally, who had experience less than 3 years by $6.3 \%$. Moreover, the table indicated that $61.1 \%$ of the respondents are supervisors and $38.9 \%$ are managers.

\section{Descriptive results of the study variables}

1- Importance of performance appraisal process in E.G.O.T.H.

A- importance of performance appraisal process for hotel

Table (3): Importance of performance appraisal process for hotel in F \& B

\begin{tabular}{|l|c|c|}
\hline \multicolumn{1}{|c|}{ Items } & Mean & SD \\
\hline knowing the extent to achieve the objectives of the hotel & 3.90 & 1.22 \\
\hline Detecting deficiencies in the performance of employees & 3.82 & 1.15 \\
\hline Providing the necessary information and data for future plans related to the employees & 3.79 & 1.26 \\
\hline Increasing the efficiency of employees & 4.03 & 1.23 \\
\hline Retaining the outstanding employees and raising their level of performance & 3.66 & 1.04 \\
\hline Verifying that training programs have achieved their objectives & 3.99 & 1.07 \\
\hline Building a strong relationship between management and employees & 3.93 & 1.06 \\
\hline Increasing the loyalty of employees to the hotel & 3.75 & 1.28 \\
\hline Developing training plans based on the specific shortcomings and problems & 3.97 & 1.17 \\
\hline Importance of performance appraisal process for hotel & 3.87 & 1.16 \\
\hline
\end{tabular}


Table (3) indicated that performance appraisal process has a high importance for hotel, as mean was 3.87, and standard deviation was 1.16. Table (9) also showed the following results:

- The mean value of 3.90 shows that the performance appraisal process helps knowing the extent to achieve the objectives of the hotel. Standard deviation value shows a normal distribution of data as it records 1.22 .

- The mean value of 3.82 shows that the performance appraisal process helps detecting deficiencies in the performance of employees. Standard deviation value shows a normal distribution of data as it records 1.15.

- The mean value of 3.79 indicates that the performance appraisal process helps providing the necessary information and data for future plans related to the employees. Standard deviation value records 1.26 .

- The mean value of 3.93 shows that the performance appraisal process helps building a strong relationship between management and employees. Standard deviation records 1.06.

- The mean value of 3.75 clarifies that the performance appraisal process helps increasing the loyalty of employees to the hotel. Standard deviation records 1.28.

- The mean value of 3.97 indicates that the performance appraisal process helps develop training plans based on the specific shortcomings and problems. Standard deviation records 1.17.

\section{B- importance of performance appraisal process for employees}

Table (4) Importance of performance appraisal process for employees in F \& B

\begin{tabular}{|l|c|c|}
\hline \multicolumn{1}{|c|}{ Items } & Mean & SD \\
\hline Developing and improving performance & 4.08 & 1.28 \\
\hline Increasing their sense of responsibility & 3.85 & 1.33 \\
\hline Raising the morale of employees & 3.54 & 1.01 \\
\hline Increasing the level of employee satisfaction & 3.72 & 1.14 \\
\hline Obtaining feedback about their achievement of the job objectives & 3.65 & 1.07 \\
\hline Increasing their productivity & 3.85 & 1.13 \\
\hline Importance of performance appraisal process for employees & 3.78 & 1.22 \\
\hline
\end{tabular}

Table (4) showed that performance appraisal process has a high importance for employee, where the mean was 3.78, and standard deviation was 1.22. Additionally, the table indicated the following results:

- The mean value of 4.08 shows that the performance appraisal process helps developing and improving performance. Standard deviation records 1.28.

- The mean value of 3.85 clarifies that the performance appraisal process helps increasing their sense of responsibility. Standard deviation records 1.33 .

- The mean value of 3.65 clarifies that the performance appraisal process helps obtaining feedback about the achievement of their job objectives. Standard deviation records 1.07.

- The mean value of 3.85 reveals that the performance appraisal process helps increasing their productivity. Standard deviation records 1.13 .

\section{2- Appraising the performance of employees in E.G.O.T.H.}

Table (5) Appraising the performance of employees in E.G.O.T.H

\begin{tabular}{|l|c|c|}
\hline \multicolumn{1}{|c|}{ Items } & Mean & SD \\
\hline F \&B employees are keen to achieve the objectives of the department efficiently & 3.59 & 1.33 \\
\hline F \&B employees complete the tasks required of them on time & 3.75 & 1.17 \\
\hline F \&B employees have the ability to work in a team effectively & 3.67 & 1.24 \\
\hline F \&B employees have good relations with their managers at work & 3.73 & 1.29 \\
\hline F \&B employees have good relations with their co-workers & 3.69 & 1.13 \\
\hline
\end{tabular}


International Journal of Heritage, Tourism and Hospitality Vol. (13), No. (2), September, 2019 By: Faculty of Tourism and Hotels, Fayoum University

\begin{tabular}{|c|c|c|}
\hline Items & Mean & SD \\
\hline F \&B employees have the ability to take responsibility for the daily workload & 3.68 & 1.21 \\
\hline F \&B employees are always committed to labor laws and regulations & 3.71 & 1.23 \\
\hline $\begin{array}{l}\text { F \&B employees have the ability to adapt to working conditions in emergency } \\
\text { situations }\end{array}$ & 3.57 & 1.19 \\
\hline F \&B employees avoid delays in coming to work & 3.54 & 1.28 \\
\hline F \&B employees always develop their way of functioning effectively & 3.57 & 1.18 \\
\hline F \&B employees coordinate and cooperate with others to carry out their work properly & 3.63 & 1.25 \\
\hline F \&B employees have full knowledge of their job requirements & 3.60 & 1.38 \\
\hline F \&B employees comply with official working hours & 3.98 & 1.19 \\
\hline F \&B employees have the ability to innovate at work & 3.54 & 1.07 \\
\hline F \&B employees have the ability to correct their mistakes effectively & 3.51 & 1.12 \\
\hline F \&B employees make the necessary effort to complete their work properly & 3.87 & 1.28 \\
\hline $\begin{array}{l}\text { F \&B employees carry out the instructions issued by their managers related to the work } \\
\text { directly }\end{array}$ & 3.63 & 1.03 \\
\hline F \&B employees can overcome the work problems they face efficiently & 3.49 & 1.25 \\
\hline F \&B employees are available outside formal working hours & 3.50 & 1.07 \\
\hline F \&B employees always look for everything new in their field of work & 3.64 & 1.27 \\
\hline F \&B employees evaluate themselves & 3.48 & 1.24 \\
\hline F \&B employees determine the training courses needed to improve their efficiency & 3.54 & 1.29 \\
\hline Appraising the performance of employees in E.G.O.T.H & 3.63 & 1.20 \\
\hline
\end{tabular}

Table (5) showed that employees in E.G.O.T.H has a relatively high performance level, as mean was 3.63, and standard deviation was 1.20. Moreover, table (11) indicated the following results:

- The mean value was 3.59 which indicates that employees in (E.G.O.T.H) are keen to achieve the overall objectives of their departments efficiently. Standard deviation value was 1.33.

- The mean value was 3.75 which highlights that employees in (E.G.O.T.H) complete the tasks required of them on time. Standard deviation value was 1.17 .

- The mean value was 3.67 which shows that employees in (E.G.O.T.H) have the ability to work in a team effectively. Standard deviation value was 1.24.

- The mean value was 3.73 which depicts that employees in (E.G.O.T.H) have good relations with their managers at work. Standard deviation value was 1.29.

- The mean value was 3.69 which illustrates that employees in (E.G.O.T.H) have good relations with their co-workers. Standard deviation value was 1.13.

- The mean value was 3.68 which reveals that employees in (E.G.O.T.H) have the ability to take responsibility for the daily workload. Standard deviation value was 1.21.

- The mean value was 3.71 which clarifies that employees in (E.G.O.T.H) are committed to labor laws and regulations. Standard deviation value was 1.23.

- The mean value was 3.60 which demonstrates that employees in (E.G.O.T.H) have full knowledge of their job requirements. Standard deviation value was 1.38.

- The mean value was 3.63 which clarifies that employees in (E.G.O.T.H) carry out the instructions issued by their managers related to the work directly. Standard deviation value was 1.03.

- The mean value was 3.49 which reveals that employees in (E.G.O.T.H) can overcome the work problems they face efficiently. Standard deviation value was 1.25.

- The mean value was 3.54 which reveals that employees in (E.G.O.T.H) determine the training courses needed to improve their efficiency. Standard deviation value was 1.29. 
International Journal of Heritage, Tourism and Hospitality Vol. (13), No. (2), September, 2019

By: Faculty of Tourism and Hotels, Fayoum University

\section{3- Challenges of performance appraisal process in E.G.O.T.H.}

Table (6) Challenges of performance appraisal process in E.G.O.T.H

\begin{tabular}{|l|c|c|}
\hline \multicolumn{1}{|c|}{ Items } & Mean & SD \\
\hline $\begin{array}{l}\text { Using of previous performance reports when evaluating the performance of } \\
\text { employees }\end{array}$ & 1.88 & 1.12 \\
\hline $\begin{array}{l}\text { The performance evaluation process is influenced by the type of employee evaluated } \\
\text { (male or female) }\end{array}$ & 1.71 & 0.92 \\
\hline $\begin{array}{l}\text { Medium grades are given in employees' performance appraisal to avoid } \\
\text { embarrassment }\end{array}$ & 1.95 & 1.03 \\
\hline Passion sometimes affects the employee's performance appraisal & 2.45 & 1.34 \\
\hline Giving the employees a low assessment to urge them to improve their performance & 1.88 & 1.08 \\
\hline $\begin{array}{l}\text { The employee's final disposition before the evaluation period, whether the action is } \\
\text { negative or positive affects the evaluation process }\end{array}$ & 1.91 & 1.04 \\
\hline $\begin{array}{l}\text { The senior management does not set specific standards or models to evaluate the } \\
\text { performance of employees }\end{array}$ & 1.82 & 1.00 \\
\hline $\begin{array}{l}\text { The senior management does not explain the purpose of the performance evaluation } \\
\text { process }\end{array}$ & 1.82 & 1.08 \\
\hline Some evaluators have not the skills to perform the performance evaluation process & 1.85 & 0.98 \\
\hline Employees fear of performance evaluation results & 3.87 & 0.93 \\
\hline Non-declaration of appraisal criteria for managers, supervisors and subordinates & 1.88 & 1.14 \\
\hline The performance appraisal process considered as a routine task that will not be used & 1.80 & 1.08 \\
\hline $\begin{array}{l}\text { The multiplicity of entities responsible for the performance appraisal process affect } \\
\text { the objectivity of the results }\end{array}$ & 1.93 & 1.14 \\
\hline $\begin{array}{l}\text { Performance appraisal criteria focus only on the external appearance of the } \\
\text { employees }\end{array}$ & 1.91 & 1.12 \\
\hline $\begin{array}{l}\text { Lack of participation of the employee to assess his performance affects the } \\
\text { performance appraisal system }\end{array}$ & 3.98 & 1.19 \\
\hline $\begin{array}{l}\text { Using ready-made models from other hotels to evaluate the performance of } \\
\text { employees }\end{array}$ & 1.97 & 1.18 \\
\hline Using traditional methods in evaluating the performance of employees & 1.74 & 0.99 \\
\hline $\begin{array}{l}\text { Using performance appraisal results to punish employees rather than for } \\
\text { developmental purposes }\end{array}$ & 1.85 & 1.03 \\
\hline The irregularity of the performance appraisal process & 1.98 & 1.17 \\
\hline
\end{tabular}

Table (6) revealed the following results:

- The mean value was 1.88 which shows that managers in (E.G.O.T.H) does not use the previous performance reports when evaluating the performance of employees in performance appraisal process. Standard deviation value was 1.12.

- The mean value was 1.71 which illustrates that the performance evaluation process is not influenced by the type of employee evaluated (male or female). Standard deviation value was .92.

- The mean value was 1.88 which highlights that managers in (E.G.O.T.H) do not give the employees a low assessment to urge them to improve their performance. Standard deviation value was 1.08 .

- The mean value was 1.82 which shows that senior management sets specific standards or models to evaluate the performance of employees in (E.G.O.T.H). Standard deviation value was 1.00 .

- The mean value was 1.82 which illustrates that senior management explains the purpose of the performance evaluation process in (E.G.O.T.H). Standard deviation value was 1.08. 
- The mean value was 3.87 which reveals that employees fear of performance evaluation results in (E.G.O.T.H). Standard deviation value was .93.

- The mean value was 1.80 which depicts that the performance appraisal process is not a routine task that will not be used in (E.G.O.T.H). Standard deviation value was 1.08.

- The mean value was 1.98 which shows that the irregularity of the performance appraisal process is not one of the challenges of performance appraisal process in (E.G.O.T.H). Standard deviation value was 1.17 .

\section{4- Importance of performance appraisal process in Accor hotel chain}

A- importance of performance appraisal process in Accor hotel chain

Table (7): Importance of performance appraisal process for hotel in F \& B

\begin{tabular}{|l|c|c|}
\hline \multicolumn{1}{|c|}{ Items } & Mean & SD \\
\hline knowing the extent to achieve the objectives of the hotel & 4.29 & 0.98 \\
\hline Detecting deficiencies in the performance of employees & 4.26 & 1.05 \\
\hline $\begin{array}{l}\text { Providing the necessary information and data for future plans related to the } \\
\text { employees }\end{array}$ & 4.29 & 1.03 \\
\hline Increasing the efficiency of employees & 4.32 & 0.96 \\
\hline Retaining the outstanding employees and raising their level of performance & 4.26 & 0.99 \\
\hline Verifying that training programs have achieved their objectives & 4.24 & 0.98 \\
\hline Building a strong relationship between management and employees & 4.28 & 1.03 \\
\hline Increasing the loyalty of employees to the hotel & 4.13 & 0.97 \\
\hline Developing training plans based on the specific shortcomings and problems & 4.28 & 1.17 \\
\hline Importance of performance appraisal process for hotel & 4.26 & 0.97 \\
\hline
\end{tabular}

Table (7) indicated that performance appraisal process has a high importance for hotel in Accor, as mean was 4.26, and standard deviation was 0.97. additionally, table (14) clarified the following results:

- The mean value of 4.29 indicated that the performance appraisal process helps knowing the extent to achieve the objectives in Accor hotel chain. Standard deviation value was .98

- The mean value of 4.44 depicts that the performance appraisal process helps detecting of problems in the employees' performance in Accor hotel chain. Standard deviation value was .94 .

- The mean value of 4.29 indicates that the performance appraisal process helps providing the necessary information and data for future plans related to the employees in Accor hotel chain. Standard deviation value was 1.03 .

- The mean value of 4.13 clarifies that the performance appraisal process helps increasing the loyalty of employees in Accor hotel chain. Standard deviation value was .97.

- The mean value of 4.28 depicts that the performance appraisal process helps develop training plans based on the specific shortcomings and problems. Standard deviation value was 1.17.

\section{B- importance of performance appraisal process for employees}

Table (8) Importance of performance appraisal process for employees in F \& B

\begin{tabular}{|l|c|c|}
\hline \multicolumn{1}{|c|}{ Items } & Mean & SD \\
\hline Developing and improving performance & 4.29 & 0.97 \\
\hline Increasing their sense of responsibility & 4.25 & 0.91 \\
\hline Raising the morale of employees & 4.31 & 0.93 \\
\hline Increasing the level of employee satisfaction & 4.26 & 1.00 \\
\hline Obtaining feedback about their achievement of the job objectives & 4.09 & 1.02 \\
\hline
\end{tabular}


International Journal of Heritage, Tourism and Hospitality Vol. (13), No. (2), September, 2019 By: Faculty of Tourism and Hotels, Fayoum University

\begin{tabular}{|l|c|c|}
\hline \multicolumn{1}{|c|}{ Items } & Mean & SD \\
\hline Increasing their productivity & 4.16 & 1.08 \\
\hline Importance of performance appraisal process for employees & 4.23 & 0.98 \\
\hline
\end{tabular}

Table (8) clarified that performance appraisal process has a high importance for employee in Accor, where the mean was 4.23, and standard deviation was 0.98. Moreover, the table showed the following results:

- The mean value of 4.29 shows that the performance appraisal process helps developing and improving performance in Accor hotel chain. Standard deviation value was .97.

- The mean value of 4.25 indicates that the performance appraisal process helps increasing their sense of responsibility. Standard deviation value was .91 .

- The mean value of 4.09 shows that the performance appraisal process helps obtaining feedback about the achievement of their job objectives. Standard deviation value was 1.02.

- The mean value of 4.16 shows that the performance appraisal process helps increasing their productivity. Standard deviation value was 1.08 .

\section{5- Appraising the performance of employees in Accor hotel chain}

Table (9) Appraising the performance of employees in Accor hotel chain

\begin{tabular}{|c|c|c|}
\hline Items & Mean & SD \\
\hline F \&B employees are keen to achieve the objectives of the department efficiently & 4.34 & 0.98 \\
\hline F \&B employees complete the tasks required of them on time & 4.17 & 1.21 \\
\hline F \&B employees have the ability to work in a team effectively & 4.39 & 0.99 \\
\hline F \&B employees have good relations with their managers at work & 4.16 & 1.01 \\
\hline F \&B employees have good relations with their co-workers & 4.29 & 0.94 \\
\hline F \&B employees have the ability to take responsibility for the daily workload & 4.36 & 0.94 \\
\hline F \&B employees are always committed to labor laws and regulations & 4.13 & 1.06 \\
\hline $\begin{array}{l}\text { F \&B employees have the ability to adapt to working conditions in emergency } \\
\text { situations }\end{array}$ & 4.17 & 1.05 \\
\hline F \&B employees avoid delays in coming to work & 4.26 & 0.96 \\
\hline F \&B employees always develop their way of functioning effectively & 4.11 & 1.11 \\
\hline $\begin{array}{l}\text { F \&B employees coordinate and cooperate with others to carry out their work } \\
\text { properly }\end{array}$ & 4.26 & 1.10 \\
\hline F \&B employees have full knowledge of their job requirements & 4.28 & 0.97 \\
\hline F \&B employees comply with official working hours & 4.24 & 1.04 \\
\hline F \&B employees have the ability to innovate at work & 4.12 & 1.19 \\
\hline F \&B employees have the ability to correct their mistakes effectively & 4.16 & 1.06 \\
\hline F \&B employees make the necessary effort to complete their work properly & 4.22 & 1.10 \\
\hline $\begin{array}{l}\text { F \&B employees carry out the instructions issued by their managers related to the } \\
\text { work directly }\end{array}$ & 4.22 & 1.12 \\
\hline F \&B employees can overcome the work problems they face efficiently & 4.25 & 0.87 \\
\hline F \&B employees are available outside formal working hours & 4.18 & 1.11 \\
\hline F \&B employees always look for everything new in their field of work & 4.11 & 1.11 \\
\hline F \&B employees evaluate themselves & 4.19 & 1.04 \\
\hline F \&B employees determine the training courses needed to improve their efficiency & 4.01 & 1.22 \\
\hline Appraising the performance of employees in Accor hotel chain & 4.21 & 1.01 \\
\hline
\end{tabular}

Table (9) revealed that employees in Accor has a high performance level, as mean was 4.21, and standard deviation was 1.01. As well as, table (16) indicated the following results: 
- The mean value was 4.34 which clarifies that employees in Accor hotel chain are keen to achieve the overall objectives of their departments efficiently. Standard deviation value was .98

- The mean value was 4.17 which depicts that employees complete the tasks required of them on time in Accor hotel chain. Standard deviation value was 1.21.

- The mean value was 4.39 which illustrates that employees in Accor hotel chain have the ability to work in a team effectively. Standard deviation value was 99 .

- The mean value was 4.16 which shows that employees in Accor hotel chain have good relations with their managers at work. Standard deviation value was 1.01.

- The mean value was 4.26 which indicates that employees avoid delays in coming to work in Accor hotel chain. Standard deviation value was .96.

- The mean value was 4.28 which highlights that employees in Accor hotel chain have full knowledge of their job requirements. Standard deviation value was .97 .

- The mean value was 4.12 which indicates that employees in Accor hotel chain have the ability to innovate at work. Standard deviation value was 1.19.

- The mean value was 4.18 which illustrates that employees in Accor hotel chain are available outside formal working hours. Standard deviation value was 1.11.

- The mean value was 4.19 which reveals that employees in Accor hotel chain evaluate themselves sometimes. Standard deviation value was 1.04.

\section{6- Challenges of performance appraisal process in Accor hotel chain}

Table (10) Challenges of performance appraisal process in Accor hotel chain

\begin{tabular}{|l|c|c|}
\hline \multicolumn{1}{|c|}{ Items } & Mean & SD \\
\hline $\begin{array}{l}\text { Using of previous performance reports when evaluating the performance of } \\
\text { employees }\end{array}$ & 1.91 & 1.16 \\
\hline $\begin{array}{l}\text { The performance evaluation process is influenced by the type of employee evaluated } \\
\text { (male or female) }\end{array}$ & 1.83 & 1.14 \\
\hline $\begin{array}{l}\text { Medium grades are given in employees' performance appraisal to avoid } \\
\text { embarrassment }\end{array}$ & 1.99 & 1.14 \\
\hline Passion sometimes affects the employee's performance appraisal & 2.29 & 1.20 \\
\hline Giving employees a low assessment to motivate them to improve their performance & 1.86 & 1.06 \\
\hline $\begin{array}{l}\text { The employee's final disposition before the evaluation period, whether the action is } \\
\text { negative or positive affects the evaluation process }\end{array}$ & 2.03 & 1.15 \\
\hline $\begin{array}{l}\text { The senior management does not set specific standards or models to evaluate the } \\
\text { performance of employees }\end{array}$ & 1.97 & 1.20 \\
\hline $\begin{array}{l}\text { The senior management does not explain the purpose of the performance evaluation } \\
\text { process }\end{array}$ & 1.89 & 1.14 \\
\hline Some evaluators have not the skills to perform the performance evaluation process & 2.01 & 1.22 \\
\hline Employees fear of performance evaluation results & 3.71 & 1.19 \\
\hline Non-declaration of appraisal criteria for managers, supervisors and subordinates & 1.84 & 1.09 \\
\hline The performance appraisal process considered as a routine task that will not be used & 1.76 & 1.04 \\
\hline $\begin{array}{l}\text { The multiplicity of entities responsible for the performance appraisal process affect } \\
\text { the objectivity of the results }\end{array}$ & 1.81 & 1.03 \\
\hline $\begin{array}{l}\text { Performance appraisal criteria focus only on the external appearance of the } \\
\text { employees }\end{array}$ & 1.76 & 0.92 \\
\hline $\begin{array}{l}\text { Lack of participation of the employee to assess his performance affects the } \\
\text { performance appraisal system }\end{array}$ & 4.02 & 1.19 \\
\hline
\end{tabular}


International Journal of Heritage, Tourism and Hospitality Vol. (13), No. (2), September, 2019

By: Faculty of Tourism and Hotels, Fayoum University

\begin{tabular}{|l|c|c|}
\hline \multicolumn{1}{|c|}{ Items } & Mean & SD \\
\hline $\begin{array}{l}\text { Using ready-made models from other hotels to evaluate the performance of } \\
\text { employees }\end{array}$ & 1.88 & 1.09 \\
\hline Using traditional methods in evaluating the performance of employees & 1.71 & 1.05 \\
\hline $\begin{array}{l}\text { Using performance appraisal results to punish employees rather than for } \\
\text { developmental purposes }\end{array}$ & 1.78 & 1.00 \\
\hline The irregularity of the performance appraisal process & 2.01 & 1.16 \\
\hline
\end{tabular}

Table (10) highlighted the following results

- The mean value was 1.91 which illustrates that managers in Accor hotel chain do not use the previous performance reports when evaluating the performance of employees in the performance appraisal process. Standard deviation value was 1.16.

- The mean value was 1.83 which shows that the performance evaluation process is not influenced by the type of employee evaluated (male or female) in Accor hotel chain. Standard deviation value was 1.14 .

- The mean value was 1.99 which shows that managers in Accor hotel chain do not give medium grades in employees' performance appraisal to avoid embarrassment. Standard deviation value was 1.14 .

- The mean value was 2.29 which clarifies that passion does not affect the employees' performance appraisal in Accor hotel chain. Standard deviation value was 1.20.

- The mean value was 1.97 which indicates that senior management sets specific standards or models to evaluate the performance of employees in Accor hotel chain. Standard deviation value was 1.20 .

- The mean value was 1.76 which shows that appraisal criteria do not focus only on the external appearance of the employees in Accor hotel chain. Standard deviation value was .92.

- The mean value was 2.01 which indicates that the irregularity of the performance appraisal process is not one of the challenges of performance appraisal process in Accor hotel chain. Standard deviation value was 1.16.

Table (11) compare between results of E.G.O.T.H and Accor. The table indicates that the mean value of importance of performance appraisal process for hotel in Accor is higher than E.G.O.T.H., where mean value is 4.26 for Accor and is 3.87 for E.G.O.T.H. Additionally, the mean value of importance of performance appraisal process for employees in Accor is higher than E.G.O.T.H., where mean value is 4.23 for Accor and is 3.78 for E.G.O.T.H. Also, table shows that employees' performance level in Accor is higher than employees' performance level in E.G.O.T.H., as mean value is 4.21 in Accor and is 3.63 in E.G.O.T.H. Finally, table reveals that there are challenges in E.G.O.T.H. and Accor at the same level, where mean value is 2.11 for both hotels.

Table (11) comparison between results of E.G.O.T.H. and Accor

\begin{tabular}{|l|c|c|c|}
\hline \multicolumn{2}{|c|}{} & E.G.O.T.H & Accor \\
\hline Importance of performance appraisal process for hotel & Mean & 3.87 & 4.26 \\
\cline { 2 - 4 } & SD & 1.16 & 0.97 \\
\hline Importance of performance appraisal process for employees & Mean & 3.78 & 4.23 \\
\cline { 2 - 4 } & SD & 1.22 & 0.98 \\
\hline Appraising the performance of employees & Mean & 3.63 & 4.21 \\
\cline { 2 - 4 } & SD & 1.20 & 1.01 \\
\hline Challenges of performance appraisal process & Mean & 2.11 & 2.11 \\
\cline { 2 - 4 } & SD & 1.13 & 2.10 \\
\hline
\end{tabular}




\section{Hypothesis Testing}

Testing the first hypothesis "There is a statistically significant relationship between the Challenges of performance appraisal process and employees' performance appraisal in the hotels under study"

To test the first hypothesis, the correlation test was performed to assess the relationship between the independent variable (Challenges of performance appraisal process) and the dependent variable (employees' performance appraisal), using the Pearson correlation coefficient.

Table (12) The relationship between the Challenges of performance appraisal process and employees' performance appraisal

\begin{tabular}{|l|l|c|c|c|c|}
\hline \multicolumn{2}{|c|}{} & \multicolumn{2}{c|}{ E.G.O.T.H. } & \multicolumn{2}{c|}{ Accor } \\
\cline { 3 - 6 } \multicolumn{2}{c|}{} & X1 & $\mathrm{X} 2$ & $\mathrm{X} 1$ & $\mathrm{X} 2$ \\
\hline \multirow{3}{*}{ X1 } & Correlation Coefficient & 1.000 & $-.701 * *$ & 1.000 & $-.715^{* *}$ \\
\cline { 2 - 5 } & Sig. (2-tailed) &. & .000 &. & .000 \\
\cline { 2 - 5 } & $\mathrm{N}$ & 136 & 136 & 152 & 152 \\
\hline \multirow{3}{*}{$\mathrm{X} 2$} & Correlation Coefficient & $-.701 * *$ & 1.000 & $-.715^{* *}$ & 1.000 \\
\cline { 2 - 6 } & Sig. (2-tailed) & .000 &. & .000 &. \\
\cline { 2 - 6 } & $\mathrm{N}$ & 136 & 136 & 152 & 152 \\
\hline
\end{tabular}

$\mathrm{X} 1=$ Challenges of performance appraisal process \& X2= employees' performance appraisal Table (12) showed a significant and negative correlation between the Challenges of performance appraisal process and employees' performance appraisal in the hotels of the Egyptian Company for Tourism and Hotels (E.G.O.T.H.) and the Accor Hotel chain. For the relationship between the Challenges of performance appraisal process and Appraising the performance of employees in the hotels of the Egyptian Company for Tourism and Hotels (E.G.O.T.H.), the correlation was 0.701 , that mean a strong and negative correlation, which indicate that the fewer the challenges of performance appraisal process, the more accurately the performance is appraised.

As for the relationship between the Challenges of performance appraisal process and Appraising the performance of employees in the Accor Hotel chain, the correlation was -0.715 , which is also a strong and correlation, that indicating that the fewer the challenges of performance appraisal process, the more accurate performance is appraised. The table shows the correlation value in Accor for E.G.O.T.H., but is fairly close, with the same result. Accordingly, the first hypothesis is accepted.

Testing the second hypothesis "There are statistical significance differences between the performance of employees in the department of food and beverages in the hotels of the Egyptian Company for Tourism and Hotels (E.G.O.T.H) and the Accor Hotel chain". To test this hypothesis, the Mann-Whitney test was used to identify the differences between two independent samples.

Table (13) The differences among E.G.O.T.H. and Accor with regard to the variable according to MannWhitney test

\begin{tabular}{|c|c|c|c|c|c|c|c|}
\hline & Hotel & $\mathrm{N}$ & $\begin{array}{l}\text { Mean } \\
\text { Rank }\end{array}$ & $\begin{array}{c}\text { Mann- } \\
\text { Whitney } \\
\text { U }\end{array}$ & $\begin{array}{c}\text { Wilcoxon } \\
\text { W }\end{array}$ & $\mathrm{Z}$ & Sig. \\
\hline \multirow{2}{*}{ Staff performance } & E.G.O.T.H. & 136 & 174.15 & \multirow[t]{2}{*}{1.659} & \multirow[t]{2}{*}{3.479} & & \multirow[b]{2}{*}{.003} \\
\hline & Accor & 152 & 191.34 & & & $\begin{array}{c}- \\
1.011\end{array}$ & \\
\hline
\end{tabular}


Table (13) clarified the results of the Mann Whitney test. The significant was 0.003 , which is lower than 0.05 , that means that there are significant differences between the performance of employees in the food and beverage department in E.G.O.T.H. and Accor. Accordingly, the second hypothesis is accepted. Thus, there are statistically significant differences between the performance of employees in the food and beverage department in the hotels of the Egyptian Company for Tourism and Hotels (EGOTH) and the Accor Hotel chain. According to the mean rank, differences are for Accor Hotel chain, which mean employees' performance in Accor is better and higher than employees' performance in EGOTH.

Testing the third hypothesis "There are statistical significance differences between the importance of performance appraisal (for hotel - for employees) in the Food and Beverage department in the hotels of the Egyptian Company for Tourism and Hotels (E.G.O.T.H.) and the Accor Hotel chain". To test this hypothesis, the Mann-Whitney test was used to identify the differences between two independent samples.

Table (14) The differences among E.G.O.T.H and Accor with regard to all variables according to Mann-Whitney test

\begin{tabular}{|c|c|c|c|c|c|c|c|}
\hline & Hotel & $\mathrm{N}$ & $\begin{array}{l}\text { Mean } \\
\text { Rank }\end{array}$ & $\begin{array}{c}\text { Mann- } \\
\text { Whitney } \\
\text { U }\end{array}$ & $\begin{array}{c}\text { Wilcoxon } \\
\text { W }\end{array}$ & $\mathrm{Z}$ & Sig. \\
\hline \multirow{2}{*}{$\begin{array}{l}\text { Importance of } \\
\text { performance appraisal } \\
\text { process for hotel }\end{array}$} & E.G.O.T.H. & 136 & 165.17 & \multirow[t]{2}{*}{1.449} & \multirow[t]{2}{*}{3.197} & \multirow[t]{2}{*}{-.974} & \multirow[t]{2}{*}{.000} \\
\hline & Accor & 152 & 177.21 & & & & \\
\hline \multirow{2}{*}{$\begin{array}{l}\text { Importance of } \\
\text { performance appraisal } \\
\text { process for employees }\end{array}$} & E.G.O.T.H. & 136 & 181.33 & \multirow[t]{2}{*}{1.741} & \multirow[t]{2}{*}{3.697} & \multirow{2}{*}{$\begin{array}{c}- \\
1.642\end{array}$} & \multirow[t]{2}{*}{.001} \\
\hline & Accor & 152 & 199.54 & & & & \\
\hline
\end{tabular}

Table (14) indicated the results of the Mann Whitney test. For the differences between E.G.O.T.H. and Accor regarding the importance of performance appraisal for the hotel, the significant was 0.000 , which is lower than 0.05 , which means that there are significant differences in the importance of performance appraisal for the hotel between E.G.O.T.H. and Accor. According to the mean rank, differences are for Accor Hotel chain, which mean managers in Accor are realized the importance of performance appraisal process for hotel more than managers in EGOTH.

As for the differences between E.G.O.T.H. and Accor with regard to the importance of performance appraisal for employees, the significant was 0.001 , which is lower than 0.05 , which means that there are significant differences in the importance of performance appraisal for employees between E.G.O.T.H. and Accor. According to the mean rank, differences are for Accor Hotel chain, which mean managers in Accor are realized the importance of performance appraisal process for employees more than managers in EGOTH. Accordingly, the third hypothesis is accepted.

Thus, there are statistically significant differences between the importance of performance appraisal (for the hotel - for the employees) in the food and beverages department in the Egyptian Company for Tourism and Hotels (E.G.O.T.H.) and the Accor Hotel chain.

\section{Conclusion}

The results indicated that importance of performance appraisal process for hotel and employees in Accor is higher than E.G.O.T.H. Additionally, employees' performance level in Accor is higher than employees' performance level in E.G.O.T.H. The results also revealed that there are 
challenges in E.G.O.T.H. and Accor at the same level. the results showed that there is a significant and negative relationship between challenges of the performance appraisal process and employees performance appraisal in the food and beverages department in both E.G.O.T.H. and Accor hotels.

Finally, the results highlighted that there is significant differences between E.G.O.T.H. and Accor regarding employees' performance in the food and beverage department, as well as the importance of the performance appraisal process for the hotel and employees. As for the differences between E.G.O.T.H. and Accor regarding F\& B employees performance; differences are for Accor Hotel chain, which mean employees' performance in Accor is better and higher than employees' performance in E.G.O.T.H. Moreover, as for the differences between E.G.O.T.H. and Accor regarding the importance of the performance appraisal process for the hotel and employees; differences are for Accor Hotel chain, which mean managers in Accor are realized the importance of performance appraisal process for hotel and employees more than managers in E.G.O.T.H.

\section{Recommendations}

- Setting clear criteria for F\& B employees' performance appraisal, characterized by fairness, accuracy, and objectivity, and emphasizing that the performance appraisal process aims to develop and improve their performance and address the shortcomings of performance rather than punishment.

- Using different methods and tools to evaluate performance according to the nature of the job, the need to use multiple models according to the type of job, and not to use a uniform model for all jobs, because of the different duties and tasks of each job, and different skills and knowledge required in each job as well.

- The need to emphasize the credibility, integrity, and fairness of the evaluation process, and avoid subjective and personal factors in the evaluation of employees' performance, which reflects the feeling of F \& B employees' satisfaction with the evaluation process.

- Training of who are responsible for the performance appraisal process, and increasing their skills in conducting the evaluation process, so as to increase the accuracy and objectivity of the evaluation. As well as informing them about the most important obstacles and challenges of performance evaluation, and the importance of preparing and arranging good performance evaluation. They should also be trained on how to analyze performance evaluation results and linking them to future training plans.

- Providing continuous feedback to the food and beverage employees about their performance evaluation, to identify the strengths and weaknesses in their performance, and discuss them, and work to address the weaknesses.

- Improving the quality of work life inside the hotels, which contributes to increasing of job involvement, thus improve their performance and increase their productivity.

- Implementing modern administrative leadership styles because of their role in increasing the satisfaction and loyalty of employees, and providing a good organizational climate that positively reflects the performance of employees.

\section{References}

Abu-Musa, J. (2008) UNRWA's Area Staff Satisfaction on Performance Appraisal System and its Incentives in the Gaza Field Office, Master Thesis, Faculty of Commerce, The Islamic University-Gaza. 
Al Mulla, A. (2012) The Impact of Culture in Performance Evaluation Procedure in the UAE Public Sector, PhD dissertation, Faculty of Business and Management, University of Gloucestershire.

Alquraan, I. (2011) Job Rotation and Its Impact on Administrative Employees Performance in UNRWA . Gaza Field Office, Master Thesis, Faculty of Commerce, Islamic University of Gaza.

Anso, S. (2014) The Impact of Performance Appraisal on Employee Performance - A Case Study of First Bank of Nigeria PLC., Master Thesis, Royal Docks Business School, University of East London.

Armstrong, M. (2006) Handbook of Human Resource Management Practice, 10th Ed., Kogan Page Limited publishes, London.

Avey, J.; Luthans F. and Jensen S. (2009) Psychological Capital: A Positive Resource for Combating Employee Stress and Turnover, Human Resource Management, 48(5), 677-693.

Awase, M. (2006) Factors affecting professional nurses in Namibia, Unpublished PhD Dissertation, University Of South Africa, Namibia, South Africa.

Bakri, Z. (2015) The Impact of Job Enrichment on the Administrative Employees' Performance Case Study: The Islamic University- Gaza, Unpublished Master Thesis, Faculty of Commerce, The Islamic University- Gaza.

De Vries, J. (2010) Is new public management really dead?, OECD Journal of Budgeting, 10(1), 87-91.

Dessler, G. (2009) A Framework for Human Resource Management, 5th Ed., Pearson Education, Inc., Upper Saddle River, New Jersey.

Elnaga, A. and Imran, A. (2013) The Effect of Training on Employee Performance, European Journal of Business and Management, 5(4), 137-147.

Gilley, A.; Gilley, J.; Quatro, S. and Dixon, P. (2009) The Praeger Handbook of Human Resource Management, Greenwood Publishing Group, Inc., USA.

Gürbüz, S. and Dikmenli, O. (2007) Performance Appraisal Biases In A Public Organization: An Emprical Study, Kocaeli Üniversitesi Sosyal Bilimler Enstitüsü Dergisi,13, 108-138.

Jønsson, T. and Jeppesen, H. (2012) A Closer Look into the Employee Influence: Organizational Commitment Relationship by Distinguishing between Commitment Forms and Influence Sources, Employee Relations, 35(1), 4-19.

Kaliprasad, M. (2006) The Human Factor II: Creating a High Performance Culture in an Organization, Technical Article Cost Engineering Journal, 48(6), 67-89.

Karatepe, O. (2013) High-Performance Work Practices and Hotel Employee Performance: The Mediation of Work Engagement, International Journal of Hospitality Management, 32, 132140.

Khan, A. (2016) Employees Perception on Performance Appraisal System in a Public Limited Company in Pakistan, International Journal of Learning and Development, 6(3), 168-200.

khan, M. (2013) Role of Performance Appraisal System on Employees Motivation, IOSR Journal of Business and Management, 66-83.

Kim, T. (2014) Performance Appraisal: Determinants of Public Employees' Acceptance, PhD Dissertation, Graduate School-Newark, Rutgers, The State University of New Jersey.

Koopmans, L.; Bernaards, C.; Hildebrandt, V.; de Vet, H. and van der Beek, A. (2013) Measuring individual work performance: Identifying and selecting indicators, Work, A Journal of Prevention, Assessment and Rehabilitation. 
Kumar, D. (2005) Performance appraisal: The importance of rater training, Journal of the Kuala Lumpur Royal Malaysia Police College, No. 40.

Milka, F.; Michael, K. and Tanui,T. (2015) Effect of Extrinsic Motivation on Employee Performance in Medium Class Hotels in Kisumu City, Kenya, European Journal of Business and Management, 7(7), 240-248.

Omusebe, J.; Gabriel, K. and Douglas, M. (2013) Effects of performance appraisal on employee productivity: A case study of Mumias Sugar Company Limited, International Journal of Innovative Research and Development, 2(9), 17-32.

Plessis, A.; Douangphichit, N. and Dodd, P. (2016) HRM in Relation to Employee Motivation and Job Performance in the Hospitality Industry, Journal of International Business Research and Marketing, 1(4), 12-21.

Plessis, E. (2015) Factors Influencing Managers' Attitudes Towards Performance Appraisal, Master Thesis, University of South Africa.

Sudin, S. (2011) Fairness of and Satisfaction with Performance Appraisal Process, Journal of Global Management, 2(1), 66-83.

Tabeel, B. (2014) Motivation and Job Performance among Nurses in Gaza Strip Governmental Hospitals - Palestine, Unpublished Master Thesis, Faculty of Commerce, The Islamic University- Gaza.

Yao, Y. and Li, Y. (2014) Analysis of Performance Appraisal System of the Daphne Company Based on KPI, Studies in Asian Social Science, 1(2), 84-92.

Zaki, H. and Al-Romeedy, B. (2018) Job security as a predictor of work alienation among Egyptian travel agencies' employees, Minia Journal of Tourism and Hospitality Research, 3(1), 47-64. 